\title{
Novel bacteriocinogenic Enterococcus hirae and Pediococcus pentosaceus strains with antilisterial activity isolated from Brazilian artisanal cheese
}

\author{
V. Q. Cavicchioli, A. C. Camargo, S. D. Todorov, and L. A. Nero' \\ Department of Veterinary Medicine, Universidade Federal de Viçosa, 36570-900, Viçosa, MG, Brazil
}

\begin{abstract}
We isolated and characterized bacteriocin producers Enterococcus hirae ST57ACC and Pediococcus pentosaceus ST65ACC from raw milk artisanal cheeses. Their bacteriocins were tolerant to temperatures from $4^{\circ} \mathrm{C}$ to $100^{\circ} \mathrm{C}$ and under sterilization conditions $\left(121^{\circ} \mathrm{C}\right.$ for 15 min). Additionally, the tested bacteriocins remained active after being exposed to $\mathrm{pH} 2.0$ to 10.0 for $2 \mathrm{~h}$. The activity of the bacteriocins was affected by proteolytic enzymes but remained stable after treatment with EDTA, sodium dodecyl sulfate, $\mathrm{NaCl}$, skim milk, and Tween 80. Cell-free supernatants were capable of inhibiting Listeria innocua and several strains of Listeria monocytogenes obtained from different sources and belonging to different serotypes. When L. monocytogenes 211 and L. monocytogenes 422 were treated with bacteriocins, growth was completely inhibited over $12 \mathrm{~h}$. Cocultures of bacteriocinogenic strains and L. monocytogenes 422 in skim milk showed that E. hirae ST57ACC could control the growth of the pathogen in the matrix after $48 \mathrm{~h}$. None of the selected isolates presented positive results on a screening panel for 25 bacteriocin-related genes, however, indicating that both strains might express novel bacteriocins.
\end{abstract}

Key words: bacteriocin, cheese, Pediococcus, Enterococcus

\section{INTRODUCTION}

Many artisanal cheeses are produced in different regions of Brazil by local small farmers who normally use raw milk in their production (Brant et al., 2007). In general, such cheeses are subjected to ripening, during which their autochthonous lactic acid bacteria (LAB) may produce substances with antimicrobial activity, such as organic acids, hydrogen peroxide, diacetyl, $\mathrm{CO}_{2}$, and bacteriocins (Deegan et al., 2006; Favaro et al., 2015). A variety of LAB can be found in milk and cheese; some have been recognized as producers of

Received September 26, 2016.

Accepted December 21, 2016.

${ }^{1}$ Corresponding author: nero@ufv.br bacteriocins and have been used to control pathogens in different food products (Dos Santos et al., 2015; Favaro et al., 2015). Listeria monocytogenes is one of the most important foodborne pathogens, because of the high mortality rates associated with listeriosis (Swaminathan and Gerner-Smidt, 2007). The occurrence of $L$. monocytogenes in cheeses is a particular cause for concern, because cheeses are often consumed without further processing, and L. monocytogenes has been reported in cheese-manufacturing plants in Brazil (Barancelli et al., 2014).

Some studies in Brazil have demonstrated the presence of bacteriocin producers in raw milk and cheeses, characterizing such products as important sources of novel LAB strains with bacteriocinogenic potential (Ortolani et al., 2010; Moraes et al., 2012; Perin et al., 2012; Tulini et al., 2013; Dos Santos et al., 2015). Bacteriocins are low-molecular-weight polypeptides or proteins that are released extracellularly, genetically encoded, and ribosomally synthesized (Klaenhammer, 1988; de Vuyst and Vandamme, 1994). After binding to surface receptors or entering host cells, bacteriocins can act in the target cell via pore formation, degradation of cellular DNA, and inhibition of peptidoglycan synthesis (de Vuyst and Vandamme, 1994; Heu et al., 2001). Bacteriocins can be used as biopreservatives by adding them directly to a food product, or by adding bacteriocinogenic LAB strains that produce these peptides in situ (Gálvez et al., 1998; Deegan et al., 2006). The latter application is particularly interesting for raw milk cheeses, where adding bacteriocinogenic LAB strains could inhibit spoilage and foodborne pathogens, improving their safety (Ross et al., 2000; Favaro et al., 2015). These qualities suggest a use for novel bacteriocinogenic strains in the dairy industry (Beshkova and Frengova, 2012). However, before using novel LAB strains as biopreservatives in foods, we need to extensively characterize their technological, safety, and virulence features, to ensure their proper use in food (Favaro et al., 2015).

The present study was aimed at isolating bacteriocinogenic LAB from an artisanal cheese produced in a specific Brazilian region, and at characterizing the antimicrobial activity of selected LAB strains and their 
bacteriocins for future use by the dairy and food industries.

\section{MATERIALS AND METHODS}

\section{LAB Selection from Artisanal Cheese}

Cheese Samples, LAB Isolation, and Identification. Four samples of artisanal cheeses, produced from unpasteurized cow's milk in Nova Venécia, Espírito Santo, Brazil, were homogenized at a 1:10 ratio with saline solution $(0.85 \% \mathrm{NaCl}$, wt/vol $)$. The obtained suspensions were diluted 10-fold in saline solution, plated on multiple plates containing $10 \mathrm{~mL}$ of de Man, Rogosa, and Sharpe agar (MRS; Becton, Dickinson and Co., Franklin Lakes, NJ), and incubated at $37^{\circ} \mathrm{C}$ for $24 \mathrm{~h}$. We used the triple-layer method described by Todorov et al. (2010) and test organisms (L. monocytogenes 211, L. monocytogenes 422, L. monocytogenes 506, Lactobacillus sakei ATCC 15521, and Enterococcus faecalis ATCC 19443) to preselect for potential producers of antimicrobial LAB. Briefly, we overlaid colonies on MRS agar plates with a second layer of agar. Then, we took plates with fewer than 50 colonies and overlaid them with $10 \mathrm{~mL}$ of semisolid brain heart infusion (BHI) agar (Becton, Dickinson and Co.) containing active growing cells from the test organisms (approximately $10^{6} \mathrm{cfu} / \mathrm{mL}$ ) and incubated them at $37^{\circ} \mathrm{C}$ for 24 h. We selected colonies with evident inhibition zones for isolation and examined them for purity, Gram staining, catalase and oxidase reactions, and the production of antimicrobial compounds, as described in the next section. All cultures (bacteriocinogenic LAB and test organisms) were stored in MRS or BHI plus $20 \%$ glycerol ( $\mathrm{vol} / \mathrm{vol})$ at $-80^{\circ} \mathrm{C}$.

Total genomic DNA of selected isolates was extracted by using the ZR Fungal/Bacterial DNA Kit (Zymo Research, Irvine, CA). The extracted DNA was quantified by a NanoDrop (Thermo Fisher Scientific, Waltham, MA) and isolates were differentiated by random amplification of polymorphic DNA (RAPD)-PCR, using primers OPL-01 (GGCATGACCT), OPL-14 (GTGACAGGCT) and OPL-20 (TGGTGGACCA) and by repetitive element palindromic (rep)-PCR (using the primer $\mathrm{GTG}_{5}$ ). Amplification reactions were performed according to Todorov et al. (2010) for RAPD-PCR as follows: 45 cycles of $1 \mathrm{~min}$ at $94^{\circ} \mathrm{C}$, and $1 \mathrm{~min}$ at $36^{\circ} \mathrm{C}$, followed by an increase to $72^{\circ} \mathrm{C}$ over 2 min. Extension of the amplified product was at $72^{\circ} \mathrm{C}$ for $5 \mathrm{~min}$. Conditions for rep-PCR were 5 min at $95^{\circ} \mathrm{C}, 30$ cycles of 30 s at $95^{\circ} \mathrm{C} ; 30 \mathrm{~s}$ at $40^{\circ} \mathrm{C}$ and $8 \mathrm{~min}$ at $65^{\circ} \mathrm{C}$, and final extension of $16 \mathrm{~min}$ at $65^{\circ} \mathrm{C}$, according to Perin and Nero (2014). The amplified products were separated by electrophoresis in $1.4 \%$ (wt/vol) agarose gels in
$0.5 \times$ Tris-acetate-EDTA (TAE) buffer at $100 \mathrm{~V}$ for 2 h. Gels were stained in TAE buffer containing GelRed (Biotium Inc., Hayward, CA). Banding patterns were analyzed using Gel Compare (version 4.1; Applied Maths, Kortrijk, Belgium).

We identified isolates by amplifying $16 \mathrm{~S}$ rRNA genes from the genomic DNA with the universal primers $8 \mathrm{~F}$ (CACGGATCCAGACTTTGATYMTGGCTCAG) and 1512R (GTGAAGCTTACGGYTAGCTTGTTACGACTT) (Felske et al., 1997). We purified the amplified fragments using the QIAquick PCR Purification Kit (Qiagen, Venlo, the Netherlands). Purified fragments were sequenced at the Center for Human Genome Studies, Institute of Biomedical Sciences, University of São Paulo, Brazil, and compared with sequences in GenBank using the Basic Local Alignment Search Tool (BLAST).

As recommended by Robredo et al. (1999) and Costa et al. (1993), we tested for the presence of genes related to the identification of Enterococcus durans (AACAGCTTACTTGACTGGACGC and GTATTGGCGCTACTACCCGTATC) and Enterococcus faecium (GCGGTAGCAGCGGTAGACCAAG and GCATTTGGTAAGACACCTACG) using PCR.

Bacteriocin Production Test and Spectrum of Activity. For individual colonies that presented an inhibitory zone in the previous test, we determined the proteinaceous nature of the antimicrobial compound as described by Dos Santos et al. (2015). Selected isolates were grown on MRS at $37^{\circ} \mathrm{C}$ for $24 \mathrm{~h}$ and cell-free supernatant was obtained by centrifugation at $10,000 \times g$ for $10 \mathrm{~min}$. The $\mathrm{pH}$ of the supernatant was adjusted to 6.0-6.5 with $1 \mathrm{M} \mathrm{NaOH}$ and treated for 10 min at $80^{\circ} \mathrm{C}$. Agar-spot test using L. monocytogenes 211, L. monocytogenes 422, L. monocytogenes 506, Lb. sakei ATCC 15521, or E. faecalis ATCC 19443 at a final concentration of $10^{5} \mathrm{cfu} / \mathrm{mL}$ was performed, and inhibition zones $>2 \mathrm{~mm}$ in diameter were considered positive.

Isolates that were identified as bacteriocinogenic were grown as described above. Then, their cell-free supernatants were obtained and treated as described above, and used to assess the inhibitory spectrum of isolates, considering as targets, strains of L. monocytogenes (different serological groups) and LAB (Table 1). Culture conditions (growth medium and incubation temperature) and the origin of the test microorganisms used are also specified in Table 1.

Bacteriocin Genes. We subjected DNA from selected strains to PCR reactions to check for the presence of the following bacteriocins: enterocin $\mathrm{A}$, enterocin $\mathrm{P}$, enterocin $\mathrm{B}$, enterocin $\mathrm{L} 50 \mathrm{~B}$, pediocin $\mathrm{PA}-1$, nisin, plantaricin $\mathrm{W}$, plantaricin $\mathrm{NC} 8$, plantaricin $\mathrm{A}$, plantaricin S, sakacinGA1, sakacin GA2, sakacin X, sakacin A, sakacin Q, sakacin G, sakacin P, sakacin 
Table 1. Inhibition zones presented by bacteriocins produced by Enterococcus hirae ST57ACC and Pediococcus pentosaceus ST65ACC, against different target microorganisms

\begin{tabular}{|c|c|c|c|c|c|}
\hline \multirow[b]{2}{*}{ Target } & \multirow[b]{2}{*}{ Isolate code ${ }^{2}$} & \multirow[b]{2}{*}{ Origin } & \multirow[b]{2}{*}{ Serotype } & \multicolumn{2}{|c|}{ Inhibition zone (mm) } \\
\hline & & & & ST57ACC & ST65ACC \\
\hline \multirow{63}{*}{ Listeria monocytogenes } & A70 & Round & $4 \mathrm{~b}$ & 13 & 18 \\
\hline & A71 & Round & $4 b$ & 12 & 17 \\
\hline & A72 & Round & $4 \mathrm{~b}$ & 12 & 18 \\
\hline & A73 & Round & $4 \mathrm{~b}$ & 10 & 19 \\
\hline & $\mathrm{A} 74$ & Round & $4 \mathrm{~b}$ & 13 & 20 \\
\hline & A75 & Round & $4 \mathrm{~b}$ & 12 & 18 \\
\hline & A512 & Chuck & $4 \mathrm{~b}$ & 18 & 26 \\
\hline & A522 & Chuck & $4 \mathrm{~b}$ & 15 & 24 \\
\hline & A536 & Loin & $4 \mathrm{~b}$ & 18 & 25 \\
\hline & A537 & Loin & $4 \mathrm{~b}$ & 18 & 26 \\
\hline & A549 & Hand & $4 \mathrm{~b}$ & 14 & 19 \\
\hline & A554 & Hand & $4 \mathrm{~b}$ & 14 & 24 \\
\hline & A593 & Hand & $4 \mathrm{~b}$ & 14 & 20 \\
\hline & A4 & Chuck & $1 / 2 b$ & 11 & 18 \\
\hline & A5 & Chuck & $1 / 2 \mathrm{~b}$ & 13 & 19 \\
\hline & A6 & Chuck & $1 / 2 b$ & 12 & 18 \\
\hline & A7 & Chuck & $1 / 2 b$ & 13 & 20 \\
\hline & A8 & Chuck & $1 / 2 \mathrm{~b}$ & 12 & 18 \\
\hline & A9 & Chuck & $1 / 2 b$ & 11 & 18 \\
\hline & A10 & Chuck & $1 / 2 \mathrm{~b}$ & 12 & 18 \\
\hline & A11 & Chuck & $1 / 2 \mathrm{c}$ & 12 & 17 \\
\hline & $\mathrm{A} 12$ & Chuck & $1 / 2 \mathrm{c}$ & 13 & 20 \\
\hline & A19 & Hand & $1^{\prime} / 2 \mathrm{c}$ & 14 & 18 \\
\hline & A20 & Hand & $1 / 2 \mathrm{c}$ & 11 & 18 \\
\hline & A45 & Chuck & $1 / 2 \mathrm{c}$ & 14 & 17 \\
\hline & A46 & Chuck & $1 / 2 \mathrm{c}$ & 14 & 17 \\
\hline & A78 & Chuck & $1 / 2 \mathrm{c}$ & 12 & 17 \\
\hline & A79 & Chuck & $1 / 2 \mathrm{c}$ & 14 & 17 \\
\hline & $\mathrm{A} 80$ & Chuck & $1 / 2 \mathrm{c}$ & 12 & 17 \\
\hline & A81 & Chuck & $1 / 2 \mathrm{c}$ & 12 & 15 \\
\hline & A82 & Chuck & $1 / 2 \mathrm{c}$ & 12 & 18 \\
\hline & A83 & Chuck & $1 / 2 \mathrm{c}$ & 12 & 19 \\
\hline & A139 & Table & $1 / 2 \mathrm{c}$ & 12 & 18 \\
\hline & A140 & Table & $1 / 2 \mathrm{c}$ & 13 & 18 \\
\hline & A142 & Table & $1 / 2 \mathrm{c}$ & 12 & 18 \\
\hline & $\mathrm{A} 170$ & Hand & $1 / 2 \mathrm{c}$ & 12 & 18 \\
\hline & A171 & Hand & $1^{\prime} / 2 \mathrm{c}$ & 14 & 15 \\
\hline & A172 & Table & $1 / 2 \mathrm{c}$ & 14 & 15 \\
\hline & $\mathrm{A} 173$ & Table & $1 / 2 \mathrm{c}$ & 13 & 15 \\
\hline & A186 & Table & $1 / 2 \mathrm{c}$ & 12 & 18 \\
\hline & $\mathrm{A} 187$ & Table & $1 / 2 \mathrm{c}$ & 12 & 17 \\
\hline & A188 & Table & $1 / 2 \mathrm{c}$ & 15 & 18 \\
\hline & A189 & Table & $1 / 2 \mathrm{c}$ & 13 & 18 \\
\hline & A190 & Hand & $1^{\prime} / 2 \mathrm{c}$ & 11 & 18 \\
\hline & A191 & Hand & $1 / 2 \mathrm{c}$ & 13 & 17 \\
\hline & A192 & Hand & $1 / 2 \mathrm{c}$ & 12 & 17 \\
\hline & A193 & Hand & $1 / 2 \mathrm{c}$ & 12 & 17 \\
\hline & A210 & Hand & $1 / 2 \mathrm{c}$ & 14 & 18 \\
\hline & A232 & Table & $1 / 2 \mathrm{c}$ & 12 & 16 \\
\hline & A233 & Table & $1 / 2 \mathrm{c}$ & 11 & 20 \\
\hline & A234 & Table & $1 / 2 \mathrm{c}$ & 13 & 17 \\
\hline & A367 & Chuck & $1 / 2 \mathrm{c}$ & 11 & 18 \\
\hline & A368 & Chuck & $1 / 2 \mathrm{c}$ & 10 & 18 \\
\hline & A371 & Chuck & $1 / 2 \mathrm{c}$ & 14 & 18 \\
\hline & A372 & Chuck & $1 / 2 \mathrm{c}$ & 12 & 18 \\
\hline & A373 & Chuck & $1^{\prime} / 2 \mathrm{c}$ & 12 & 17 \\
\hline & A 505 & Loin & $1 / 2 \mathrm{c}$ & 13 & 17 \\
\hline & A506 & Loin & $1 / 2 \mathrm{c}$ & 12 & 17 \\
\hline & A 507 & Loin & $1 / 2 \mathrm{c}$ & 13 & 14 \\
\hline & A508 & Loin & $1 / 2 \mathrm{c}$ & 14 & 16 \\
\hline & A509 & Chuck & $1 / 2 \mathrm{c}$ & 12 & 14 \\
\hline & A510 & Chuck & $1 / 2 \mathrm{c}$ & 17 & 22 \\
\hline & A511 & Chuck & $1^{\prime} / 2 \mathrm{c}$ & 16 & 24 \\
\hline
\end{tabular}


Table 1 (Continued). Inhibition zones presented by bacteriocins produced by Enterococcus hirae ST57ACC and Pediococcus pentosaceus ST65ACC, against different target microorganisms ${ }^{1}$

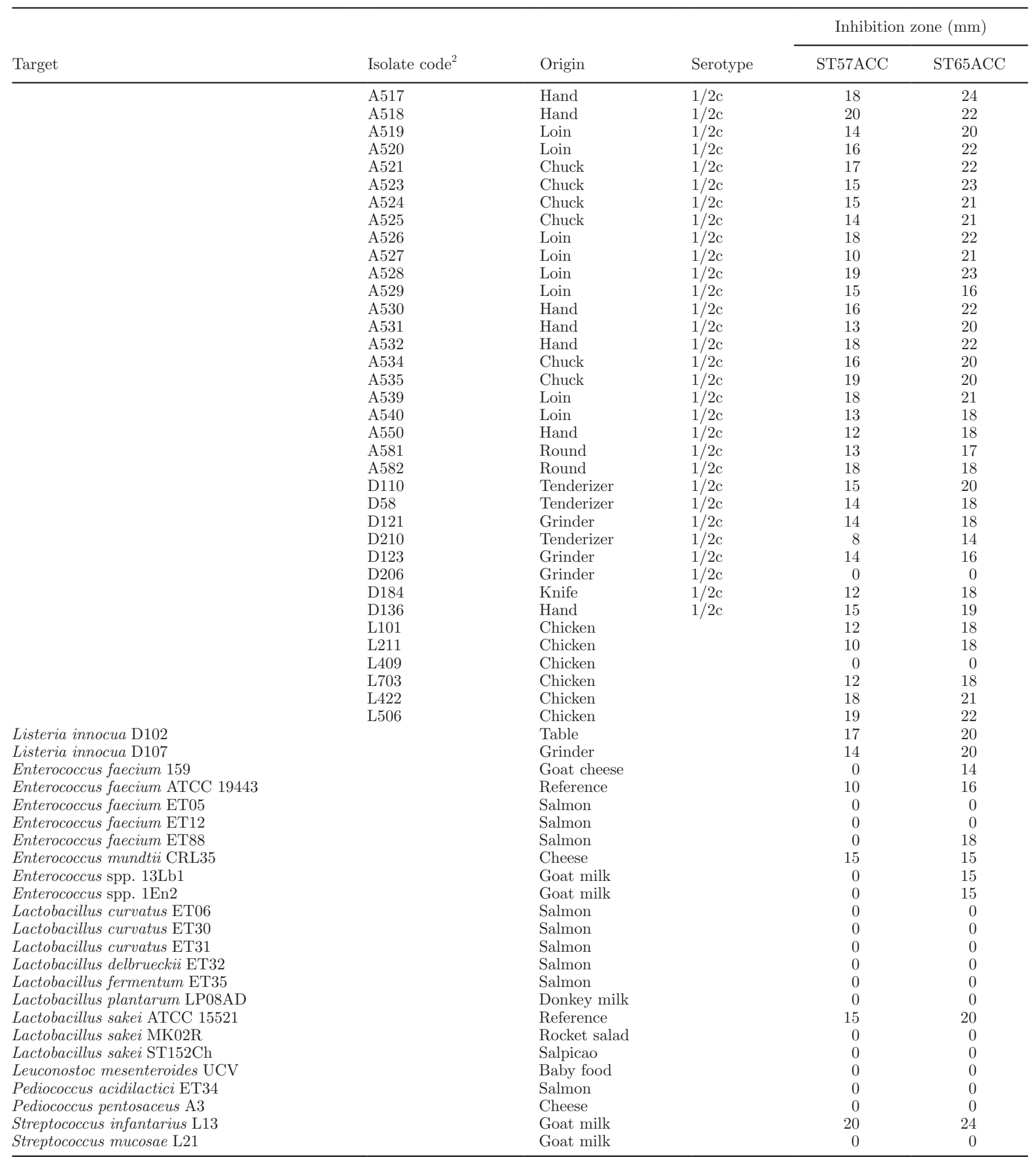

${ }^{1}$ Listeria spp. were cultured in brain heart infusion agar at $37^{\circ} \mathrm{C}$. Lactic acid bacteria were cultured in de Man, Rogosa and Sharpe broth at $37^{\circ} \mathrm{C}$. ${ }^{2}$ Isolate code refers to laboratory identification of isolates. 
Table 2. Effect of proteolytic enzymes, temperature, and $\mathrm{pH}$ on activity of the bacteriocin produced by Enterococcus hirae ST57ACC and Pediococcus pentosaceus ST65 ACC ${ }^{1}$

\begin{tabular}{|c|c|c|}
\hline Treatment & $\begin{array}{l}\text { E. hirae } \\
\text { ST57ACC }\end{array}$ & $\begin{array}{l}\text { P. pentosaceus } \\
\text { ST65ACC }\end{array}$ \\
\hline \multicolumn{3}{|l|}{ Enzyme } \\
\hline Proteinase K & - & - \\
\hline Trypsin & - & - \\
\hline Pepsin & - & - \\
\hline$\alpha$-Chymotrypsin & - & - \\
\hline Protease type XIV & - & - \\
\hline$\alpha$-Amylase & + & + \\
\hline Lipase & + & + \\
\hline \multicolumn{3}{|l|}{ Temperature (time) } \\
\hline $4-100^{\circ} \mathrm{C}(60 \mathrm{~min})$ & + & + \\
\hline $121^{\circ} \mathrm{C}(15 \mathrm{~min})$ & + & + \\
\hline \multicolumn{3}{|l|}{$\mathrm{pH}$} \\
\hline $2.0-6.0$ & + & + \\
\hline 8.0 & + & + \\
\hline 10.0 & + & + \\
\hline
\end{tabular}

${ }^{1}$ Where - represents loss of bacteriocin activity; + represents stable activity.

$\mathrm{T} \alpha$, sakacin $\mathrm{T} \beta$, lactacin 481 , lactacin $\mathrm{A}$, lactacin $\mathrm{M}$, lactacin 3147, lactacin GQ, and leuconocin 972. We prepared the $\mathrm{PCR}$ reactions using primers at a concentration of $10 \mathrm{pmol} / \mu \mathrm{L}$ and the conditions described previously (Aymerich et al., 1996; Cintas et al., 1998; Du Toit et al., 2000; Barbosa et al., 2014; Furtado et al., 2015; de Souza Barbosa et al., 2015; Favaro et al., 2015; Barbosa et al., 2016). For each PCR reaction, we adjusted the annealing temperatures according to the specifications of the primers used. The amplified products were separated by electrophoresis on agarose gels in $0.5 \times$ TAE buffer. We stained agarose gels in $0.5 \times$ TAE buffer in the presence of GelRed (Biotium Inc.) and visualized them on an LPIX transilluminator (Loccus Biotecnologia, São Paulo, Brazil).

\section{Bacteriocin Production by Selected LAB}

We treated the cell-free supernatants from the selected isolates, obtained as described above, with 0.1 $\mathrm{mg} / \mathrm{mL}$ (final concentration) of selected proteolytic enzymes, $\alpha$-amylase, and lipase (Table 2) at $37^{\circ} \mathrm{C}$ for $1 \mathrm{~h}$, and then deactivated enzymes by thermal treatment at $98^{\circ} \mathrm{C}$ for $3 \mathrm{~min}$. We determined antimicrobial activity as described above against $L$. monocytogenes 211, L. monocytogenes 422, L. monocytogenes 506, Lb. sakei ATCC 15521, and E. faecalis ATCC 19443. Cellfree supernatants with no enzyme treatments served as controls.

We also tested cell-free supernatants for the effects of $\mathrm{pH}$, temperature, and enzymes on the stability of the antimicrobial substance(s) produced (Table 2), as described by Todorov and Dicks (2006). The effect of $\mathrm{pH}$ on the bacteriocins was determined by adjusting the cell-free supernatants from $\mathrm{pH} 2.0$ to 10.0 with sterile $1 \mathrm{~N} \mathrm{HCl}$ or $1 \mathrm{~N} \mathrm{NaOH}$. After $2 \mathrm{~h}$ of incubation at $30^{\circ} \mathrm{C}$, the samples were readjusted to $\mathrm{pH} 6.5$ and the activity was tested as described before. The effect of temperature on the bacteriocins was tested by cooling or heating the cell-free to $4,20,25,30,37,45,60,80$, and $100^{\circ} \mathrm{C}$, respectively. Residual bacteriocin activity was tested after 15, 30,60, and 120 min at each of these temperatures as previously described. Additionally, the activity was tested after exposing the bacteriocins to $121^{\circ} \mathrm{C}$ for $15 \mathrm{~min}$. The effect of detergents and chemicals (EDTA, SDS, NaCl, skim milk, Tween 80) on the bacteriocins was assessed by adding $1 \%$ (wt/vol, final concentration) to the cell-free supernatants. Untreated cell-free supernatants and surfactants at the latter concentrations served as controls. All treated supernatants were incubated at $37^{\circ} \mathrm{C}$ for $3 \mathrm{~h}$, and then we tested activity as previously described. For these tests, we used L. monocytogenes 211, L. monocytogenes $422, L$. monocytogenes 506, Lb. sakei ATCC 15521, and E. faecalis ATCC 19443 as target organisms and non-treated cell-free supernatants as controls.

\section{Inhibitory Activity of Bacteriocins}

Effect of Cell-Free Supernatant on Actively Growing Cultures. One hundred milliliters of BHI broth was inoculated with $1 \%$ (vol/vol) overnight culture of L. monocytogenes 211 and L. monocytogenes 422 , respectively, and incubated the culture at $37^{\circ} \mathrm{C}$ for $3 \mathrm{~h}$. Then, we added $20 \mathrm{~mL}$ of filter-sterilized cell-free supernatant containing bacteriocins of selected LAB to the culture and recorded changes in optical density at $600 \mathrm{~nm}$ every hour for $12 \mathrm{~h}$. We recorded the cell counts of L. monocytogenes 211 and L. monocytogenes 422 by pour-plating aliquots of the cultures on BHI supplemented with $2 \%$ agar and incubated at $37^{\circ} \mathrm{C}$ for $48 \mathrm{~h}$. Results were expressed in colony-forming units per milliliter.

Coculture with Listeria monocytogenes in Milk. After optimizing bacteriocin production, we individually inoculated overnight cultures of selected bacteriocinogenic LAB strains onto $10 \%$ (wt/vol) reconstituted skim milk at concentrations of $2.0 \%$ (vol/ $\mathrm{vol}$ ), as equivalents of approximately $10^{7} \mathrm{cfu} / \mathrm{mL}$. We incubated mixed cultures at $37^{\circ} \mathrm{C}$ for $48 \mathrm{~h}$, and at $3 \mathrm{~h}$ intervals, we obtained aliquots and measured $\mathrm{pH}$ (W3B pH meter; BEL, Piracicaba, SP, Brazil). We obtained Listeria counts by surface plating aliquots onto Chromogenic Listeria agar (Oxoid, Basingstoke, UK) and incubating at $35^{\circ} \mathrm{C}$ for $48 \mathrm{~h}$. We obtained LAB counts by pour-plating aliquots on MRS agar and incubating at $37^{\circ} \mathrm{C}$ for $24 \mathrm{~h}$. Microbial counts were expressed as log colony-forming units per milliliter. In parallel, we 
tested aliquots for the presence of bacteriocins, as described above, using L. monocytogenes 422 as the target organism.

\section{RESULTS AND DISCUSSION}

\section{LAB Selection from Artisanal Cheese}

Cheese production is a traditional part of the Brazilian dairy industry, and it includes artisanal practices. The safety of artisanal cheeses is an important issue, because they are widely consumed by the public, and alternative methods to ensure their safety are needed. The Brazilian Ministry of Health and the Brazilian Ministry of Agriculture, Livestock, and Food Supply have established production, quality, and safety standards for these cheeses to ensure consumer health (Brazil, 2001, 2011). Different quality-assurance tools can be adopted by dairy industries to ensure the safety and quality of end products (Cusato et al., 2013, 2014), and bacteriocinogenic strains, bacteriocins, or both, can be among these tools.

The cheese samples included in this study presented $\mathrm{LAB}$ populations ranging from $7.36 \times 10^{4}$ to $2.21 \times$ $10^{6} \mathrm{cfu} / \mathrm{g}$. However, after adding the agar overlay to the target organisms, only 1 sample presented colonies with inhibitory activity. Following this step, we selected 84 colonies due to their inhibitory activity and tested them for the production of bacteriocins. Based on the results obtained, 2 isolates, both gram-positive cocci, presented bacteriocinogenic activity, and were catalaseand oxidase-negative.

Based on the RAPD-PCR and rep-PCR profiles, we determined that the isolates were different strains. After16S rRNA analysis, we identified them as Enterococcus hirae (ST57ACC) and Pediococcus pentosaceus (ST65ACC). Because 16S rRNA analysis does not usually provide accurate data for identifying Enterococcus spp. strains (Costa et al., 1993; Robredo et al., 1999), we performed additional PCR targeting specific genes for Enterococcus durans and Enterococcus faecium, generating negative results and confirming our finding that isolate ST57ACC was E. hirae.

The presence of Enterococcus spp. in raw milk products is not surprising, particularly in cheeses. Different Enterococcus spp., including bacteriocin producers, have previously been isolated from artisanal cheeses from different regions of Brazil, as well as worldwide (Vera Pingitore et al., 2012; Rehaiem et al., 2012; Tuncer et al., 2013; Dos Santos et al., 2015; Kırmaci et al., 2015).

The presence of $P$. pentosaceus was surprising, given that strain ST65ACC could not use lactose in its metabolite pathway (data not shown). However, Pediococcus spp. have been identified in many cheeses from different regions (Gerasi et al., 2003; Gurira and Buys, 2005; El-Baradei et al., 2007). Carafa et al. (2015) characterized the LAB from traditional Mountain Malga cheese, which is made in small farms in Italy using raw cow milk and spontaneous fermentation, and they found that $P$. pentosaceus was among the dominant species. In addition, the antimicrobial activity of Pediococcus spp. isolated from cheeses has already been reported, and their inhibitory activity against Listeria species have been previously demonstrated (Gurira and Buys, 2005; Altuntas et al., 2014).

Based on screening for the presence of different bacteriocin genes, none of the selected isolates presented positive results for the targets considered in this study. These findings indicate that both strains likely expressed novel bacteriocins, different from those in the gene screening panel. The presence of genes for bacteriocin production is often incorrectly interpreted as evidence for the expression of these genes.

Bacteriocins produced by $E$. hirae ST57ACC and $P$. pentosaceus ST65ACC inhibited all tested L. monocytogenes strains (99 in total) and 2 strains of Listeria innocua used in this study (Table 1). It is important to underline that the L. monocytogenes tested were from different serological groups and isolated from various ecological niches, including food-processing environments. Both of the studied bacteriocins expressed only limited activity against the LAB tested as sensitive strains. These results are relevant for food industries, because they indicate that the bacteriocins produced by these strains were not active against potential starter cultures added to fermented products, highlighting the bacteriocins' potential as biopreservatives.

\section{Bacteriocin Production by Selected LAB}

After contact with proteolytic enzymes, both cellfree supernatants lost activity, pointing to the protein nature of the antimicrobial compounds produced by $E$. hirae ST57ACC and P. pentosaceus ST65ACC (Table 2 ). Moreover, the presence of $\alpha$-amylase or lipase did not affect bacteriocin activity (Table 2), indicating that their antimicrobial characteristics were not related to the presence of a glycolytic or lipolytic moiety of the bacteriocin molecule.

Both of the studied bacteriocins demonstrated significant stability after treatment for up to $2 \mathrm{~h}$ at different temperatures (Table 2). Similar findings have been described for other bacteriocins produced by Enterococcus spp. and Pediococcus spp. (Gurira and Buys, 2005; Altuntaş et al., 2014; Cavicchioli et al., 2015). The thermal stability of bacteriocins is considered to be a positive feature, allowing them to be applied for biopreservation in products that will be exposed to 



Figure 1. Effect of bacteriocins produced by Enterococcus hirae ST57ACC and Pediococcus pentosaceus ST65ACC on growth of (A) Listeria monocytogenes 211, and (B) L. monocytogenes 422 , by optical density at $600 \mathrm{~nm}$. = L. monocytogenes growth (control, no bacteriocins added); $\mathbf{\square}=L$. monocytogenes growth with bacteriocin from $E$. hirae ST57ACC; $\square=$ L. monocytogenes growth with bacteriocin from $P$. pentosaceus ST65ACC. Arrows indicate the addition of cell-free supernatant containing bacteriocins.

pasteurization or other thermal treatments to ensure the safety and extended shelf life of food products. For potential medical (human and veterinary) applications of bacteriocins, sterile applied products are necessary, and the stability of bacteriocins after exposure to sterilization processes is essential.

When cell-free supernatants produced by E. hirae ST57ACC and P. pentosaceus ST65ACC were corrected to different $\mathrm{pH}$ values (from 2.0 to 10.0), we observed only a low-level reduction of antimicrobial activity at pH 9.0 and 10.0 for both bacteriocins. In the rest of the experiments, we observed no changes in antimicrobial activity compared with the untreated cell-free supernatants. Such results were not unusual, because most known bacteriocins, including nisin, are known to be stable at both neutral and acidic pH (Barbosa et al., 2014; de Souza Barbosa et al., 2015).
We observed that EDTA, SDS, NaCl, skim milk, and Tween 80 had no effect on the stability of bacteriocins produced by $E$. hirae ST57ACC and $P$. pentosaceus ST65ACC, as reported by other authors (Gálvez et al., 1998; Ivanova et al., 2000; Todorov and Dicks, 2005).

\section{Inhibitory Activity of Bacteriocins}

The growth of L. monocytogenes 211 and L. monocytogenes 422 treated with cell-free supernatants containing bacteriocins produced by $E$. hirae ST57ACC and $P$. pentosaceus ST65ACC, was completely inhibited over a period of $12 \mathrm{~h}$ (Figure 1). Over the same period, controls of L. monocytogenes 211 and L. monocytogenes 422 reached growth of approximately $10^{7} \mathrm{cfu} / \mathrm{mL}$ (Figure 1). The cell count of L. monocytogenes 211 and $L$. monocytogenes 422 in the treated samples was lower than the detection threshold.

When both strains were cultured in skim milk at 25, 30 , and $37^{\circ} \mathrm{C}$, we recorded similar growth results at 12,24 , and $36 \mathrm{~h}$. However, bacteriocin production was higher at $37^{\circ} \mathrm{C}$ (data not shown). We considered these results to be a preliminary test for choosing the ideal temperature and incubation time for the study of bacteriocin production by E. hirae ST57ACC and P. pentosaceus ST65ACC in skim milk. Results for cocultures of selected LAB strains and L. monocytogenes in milk are presented in Figure 2. Cell numbers of L. monocytogenes 422 decreased from $\log 4.37 \mathrm{cfu} / \mathrm{mL}$ (time 0 ) to $\log 1.48 \mathrm{cfu} / \mathrm{mL}$ at $36 \mathrm{~h}$ and to undetectable levels after $48 \mathrm{~h}$, highlighting the high antilisterial activity of bacteriocins produced by E. hirae ST57ACC in these matrices. Enterococcus spp. are important in the field of food microbiology, mainly because of their contribution to different fermentation processes; their functionality has been observed in dairy and meat products (Giraffa, 2003; Vera Pingitore et al., 2012). According to Achemchem et al. (2006), coculture experiments with E. faecium F58 and L. monocytogenes in goat's milk did not eliminate the pathogen, but did promote reductions in its populations of $\log 1$ to 4 . In addition, when $L$. monocytogenes contamination was reported after $12 \mathrm{~h}$ of E. faecium F58 growth in milk, the pathogen was eliminated after $130 \mathrm{~h}$ of coculture. In another experiment, E. faecalis EJ97 was also able to produce enterocin during cocultivation with $L$. monocytogenes in skim milk; however, its capacity to control the pathogen was limited to populations of $10^{3} \mathrm{cfu} / \mathrm{mL}$ or lower (García et al., 2003). In our experiment, we demonstrated that E. hirae ST57ACC could eliminate L. monocytogenes in milk after $48 \mathrm{~h}$ of inoculation, demonstrating its potential for controlling this pathogen in milk (Figure 2).

Regarding the counts of control and cocultures of $P$. pentosaceus ST65ACC and L. monocytogenes 422, we 


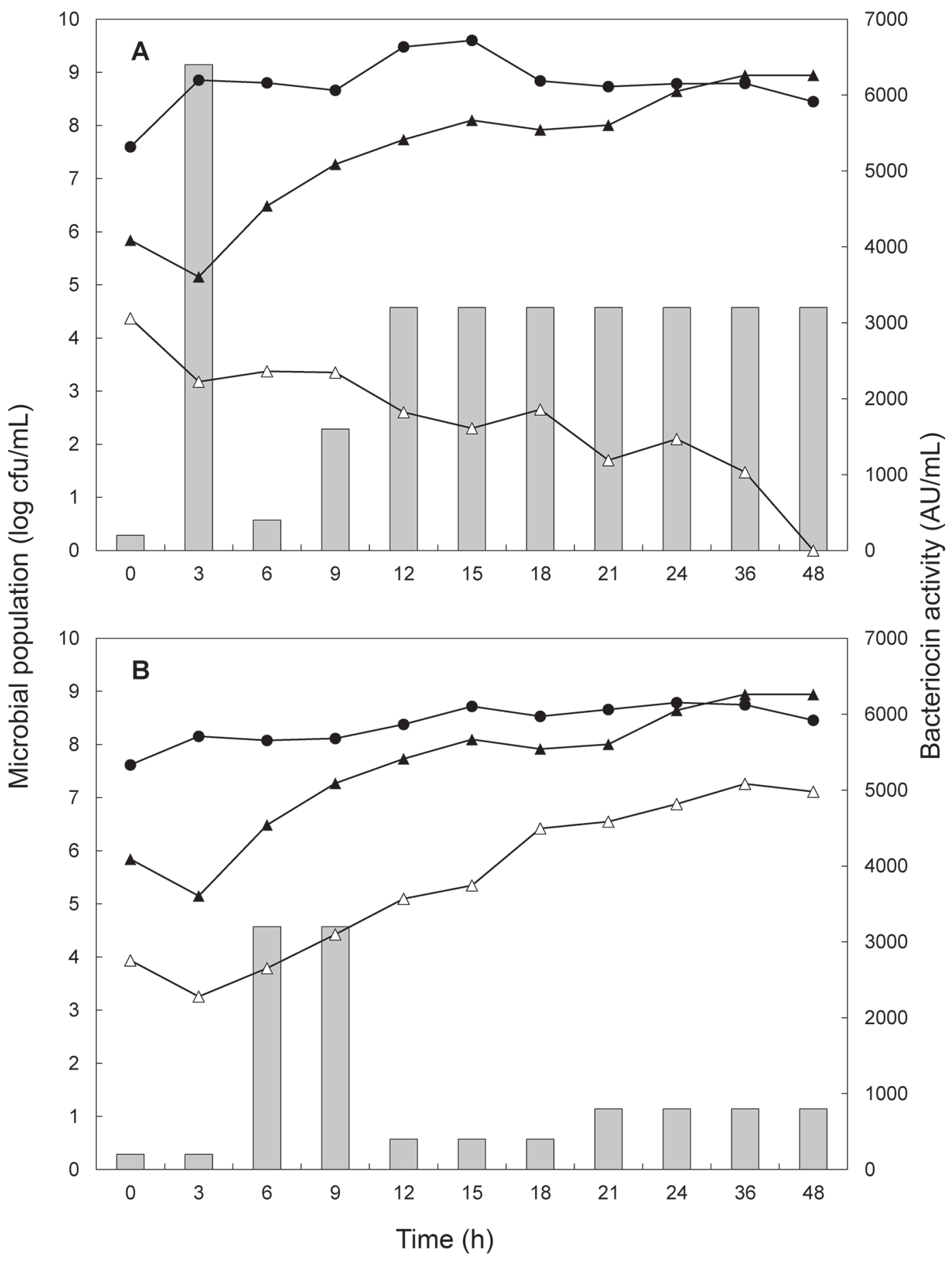

Figure 2. Growth curves and bacteriocin production of (A) Enterococcus hirae ST57ACC, and (B) Pediococcus pentosaceus ST65ACC cocultured with Listeria monocytogenes 422 in skim milk $10 \%$. = growth (log cfu/mL) of (A) E. hirae ST57ACC and (B) P. pentosaceus ST65ACC; $\boldsymbol{\Delta}=$ growth of L. monocytogenes $422(\log \mathrm{cfu} / \mathrm{mL})$ without bacteriocin added; $\Delta$ = growth of L. monocytogenes $422(\log \mathrm{cfu} / \mathrm{mL})$ with bacteriocin added; gray bars = bacteriocin activity (arbitrary units $/ \mathrm{mL}$ ).

had the opposite results. The cell numbers of L. monocytogenes 422 increased from $\log 3.94 \mathrm{cfu} / \mathrm{mL}$ (time 0 ) to $\log 7.26 \mathrm{cfu} / \mathrm{mL}$ after $36 \mathrm{~h}$ and $\log 7.11 \mathrm{cfu} / \mathrm{mL}$ after $48 \mathrm{~h}$ (Figure 2). Therefore, P. pentosaceus did not show antilisterial activity in the tested milk matrix, probably due to the limitation of the fermentation of lactose and low levels of bacteriocins detected. However, the inhibitory profile of $P$. pentosaceus in other products (such 
as meat or fermented fruit products) may be different, and should be evaluated in future studies.

Cheese production involves a combination of microbiological and biochemical processes that can be simplified as precipitation of milk proteins and maturation. Starter and non-starter cultures have specific roles in the organoleptic characteristics of cheeses (Ross et al., 2000), but special attention has been given to their antimicrobial potential to prevent foodborne pathogen grown and spoilage (Favaro et al., 2015). Considering these goals, the search for autochthonous LAB from different cheeses that are capable of producing antimicrobial substances as bacteriocins may be an answer for controlling spoilage and pathogenic microorganisms, ensuring the quality and safety of dairy products. Many examples of bacteriocinogenic LAB isolated from cheeses have already been reported (Ross et al., 2000; Dos Santos et al., 2015; Favaro et al., 2015). However, selecting novel bacteriocinogenic LAB strains may be a way to find alternatives for biopreservation in the dairy and other food industries (Beshkova and Frengova, 2012). Still, these LAB strains need to be carefully examined for their technological and biopreservation properties, and for their safety, considering virulence factors, antibiotic resistance, and the production of biogenic amines.

\section{CONCLUSIONS}

We isolated bacteriocinogenic E. hirae ST57ACC and $P$. pentosaceus ST65ACC from raw milk cheese, showing strong antilisterial activity with bacteriocins resistant to conditions that can be found in food processing. These isolates could affect the development of new industrially important cultures to control $L$. monocytogenes in the manufacture of food products. As these peptides can be new bacteriocins, future studies are required to identify them.

\section{ACKNOWLEDGMENTS}

The authors thank Conselho Nacional de Desenvolvimento Cientifico e Tecnológico (CNPq, Brasilia, Brazil), Coordenação de Aperfeiçoamento de Pessoal de Nivel Superior (CAPES, Brasilia, Brazil), and Fundação de Amparo à Pesquisa do Estado de Minas Gerais (FAPEMIG, Belo Horizonte, Brazil) for financial support.

\section{REFERENCES}

Achemchem, F., J. Abrini, M. Martinez-Bueno, E. Valdivia, and M. Maqueda. 2006. Control of Listeria monocytogenes in goat's milk and goat's Jben by the bacteriocinogenic Enterococcus faecium F58 strain. J. Food Prot. 69:2370-2376.
Altuntaş, E. G., K. Ayhan, S. Peker, B. Ayhan, and D. Ö. Demiralp. 2014. Purification and mass spectrometry based characterization of a pediocin produced by Pediococcus acidilactici 13. Mol. Biol. Rep. 41:6879-6885.

Aymerich, T., H. Holo, L. S. Håvarstein, M. Hugas, M. Garriga, and I. F. Nes. 1996. Biochemical and genetic characterization of enterocin A from Enterococcus faecium, a new antilisterial bacteriocin in the pediocin family of bacteriocins. Appl. Environ. Microbiol. 62:1676-1682.

Barancelli, G. V., T. M. Camargo, N. G. Gagliardi, E. Porto, R. A. Souza, F. Campioni, J. P. Falcão, E. Hofer, A. G. Cruz, and C. A. F. Oliveira. 2014. Pulsed-field gel electrophoresis characterization of Listeria monocytogenes isolates from cheese manufacturing plants in São Paulo, Brazil. Int. J. Food Microbiol. 173:21-29.

Barbosa, M. S., S. D. Todorov, Y. Belguesmia, Y. Choiset, H. Rabesona, I. V. Ivanova, J. M. Chobert, T. Haertlé, and B. D. G. M. Franco. 2014. Purification and characterization of the bacteriocin produced by Lactobacillus sakei MBSa1 isolated from Brazilian salami. J. Appl. Microbiol. 116:1195-1208.

Barbosa, M. S., S. D. Todorov, I. V. Ivanova, Y. Belguesmia, Y. Choiset, H. Rabesona, J. M. Chobert, T. Haertlé, and B. D. G. M. Franco. 2016. Characterization of a two-peptide plantaricin produced by Lactobacillus plantarum MBSa4 isolated from Brazilian salami. Food Contr. 60:103-112.

Beshkova, D., and G. Frengova. 2012. Bacteriocins from lactic acid bacteria: Microorganisms of potential biotechnological importance for the dairy industry. Eng. Life Sci. 12:419-432.

Brant, L. M. F., L. M. Fonseca, and M. C. C. Silva. 2007. Avaliação da qualidade microbiológica do queijo-de-minas artesanal do SerroMG. Arq. Bras. Med. Vet. Zootec. 59:1570-1574. [In Portuguese]

Brazil. 2001. RDC $\mathrm{n}^{\mathrm{O}} 12$, de 02 de janeiro de 2001. Aprovar o Regulamento Técnico sobre padrões microbiológicos para alimentos. Ministério da Saúde, Brasília, Brazil. [In Portuguese]

Brazil. 2011. Instrução Normativa n. 57-Estabelecimento de critérios para a produção de queijos artesanais. In Diário Oficial da União. 16/12/2011 ed. Ministério da Agricultura, Pecuária e Abastecimento (MAPA), ed. MAPA, DF, Brasília, Brazil. [In Portuguese]

Carafa, I., T. Nardin, R. Larcher, R. Viola, K. Tuohy, and E. Franciosi. 2015. Identification and characterization of wild lactobacill and pediococci from spontaneously fermented Mountain cheese. Food Microbiol. 48:123-132.

Cavicchioli, V. Q., W. S. Dornellas, L. M. Perin, F. A. Pieri, B. D. G. M. Franco, S. D. Todorov, and L. A. Nero. 2015. Genetic diversity and some aspects of antimicrobial activity of lactic acid bacteria isolated from goat milk. Appl. Biochem. Biotechnol. 175:28062822

Cintas, L. M., P. Casaus, H. Holo, P. E. Hernandez, I. F. Nes, and L. S Håvarstein. 1998. Enterocins L50A and L50B, two novel bacteriocins from Enterococcus faecium L50, are related to staphylococcal hemolysins. J. Bacteriol. 180:1988-1994.

Costa, Y., M. Galimand, R. Leclercq, J. Duval, and P. Courvalin. 1993. Characterization of the chromosomal aac $\left(6^{\prime}\right)$-Ii gene specific for Enterococcus faecium. Antimicrob. Agents Chemother. 37:1896-1903.

Cusato, S., A. H. Gameiro, C. H. Corassin, A. S. Sant'Ana, A. G. Cruz, J. A. F. Faria, and C. A. F. de Oliveira. 2013. Food safety systems in a small dairy factory: Implementation, major challenges, and assessment of systems' performances. Foodborne Pathog. Dis. 10:6-12.

Cusato, S., A. H. Gameiro, A. S. Sant'Ana, C. H. Corassin, A. G. Cruz, and C. A. F. d. Oliveira. 2014. Assessing the costs involved in the implementation of GMP and HACCP in a small dairy factory. Qual. Assur. Saf. Crops Foods 6:135-139.

Deegan, L. H., P. D. Cotter, C. Hill, and P. Ross. 2006. Bacteriocins: Biological tools for bio-preservation and shelf-life extension. Int. Dairy J. 16:1058-1071.

de Souza Barbosa, M., S. D. Todorov, I. V. Ivanova, J. M. Chobert, T. Haertlé, and B. D. G. M. Franco. 2015. Improving safety of salami by application of bacteriocins produced by an autochthonous Lactobacillus curvatus isolate. Food Microbiol. 46:254-262. 
Dos Santos, K. M., A. D. Vieira, H. O. Salles, J. S. Oliveira, C. R. Rocha, M. F. Borges, L. M. Bruno, B. D. Franco, and S. D. Todorov. 2015. Safety, beneficial and technological properties of Enterococcus faecium isolated from Brazilian cheeses. Braz. J. Microbiol. 46:237-249.

Du Toit, M., C. M. A. P. Franz, L. M. T. Dicks, and W. H. Holzapfel. 2000. Preliminary characterization of bacteriocins produced by Enterococcus faecium and Enterococcus faecalis isolated from pig faeces. J. Appl. Microbiol. 88:482-494.

El-Baradei, G., A. Delacroix-Buchet, and J. Ogier. 2007. Biodiversity of bacterial ecosystems in traditional Egyptian Domiati cheese. Appl. Environ. Microbiol. 73:1248-1255.

Favaro, L., A. L. B. Penna, and S. D. Todorov. 2015. Bacteriocinogenic LAB from cheeses-Application in biopreservation? Trends Food Sci. Technol. 41:37-48.

Felske, A., H. Rheims, A. Wolterink, E. Stackebrandt, and A. D. L. Akkermans. 1997. Ribosome analysis reveals prominent activity of an uncultured member of the class Actinobacteria in grassland soils. Microbiology 143:2983-2989.

Furtado, D. N., S. D. Todorov, M. Landgraf, M. T. Destro, and B. D. G. M. Franco. 2015. Bacteriocinogenic Lactococcus lactis ssp. lactis DF04Mi isolated from goat milk: Characterization of the bacteriocin. Braz. J. Microbiol. 45:1541-1550.

Gálvez, A., E. Valdivia, H. Abriouel, E. Camafeita, E. Mendez, M. Martínez-Bueno, and M. Maqueda. 1998. Isolation and characterization of enterocin EJ97, a bacteriocin produced by Enterococcus faecalis EJ97. Arch. Microbiol. 171:59-65.

García, M. T., N. Ben Omar, R. Lucas, R. Pérez-Pulido, A. Castro, M. J. Grande, M. Martínez-Cañamero, and A. Gálvez. 2003. Antimicrobial activity of enterocin EJ97 on Bacillus coagulans CECT 12. Food Microbiol. 20:533-536.

Gerasi, E., E. Litopoulou-Tzanetaki, and N. Tzanetakis. 2003. Microbiological study of Manura, a hard cheese made from raw ovine milk in the Greek island Sifnos. Int. J. Dairy Technol. 56:117-122.

Giraffa, G. 2003. Functionality of enterococci in dairy products. Int. J. Food Microbiol. 88:215-222.

Gurira, O. Z., and E. M. Buys. 2005. Characterization and antimicrobial activity of Pediococcus species isolated from South African farm-style cheese. Food Microbiol. 22:159-168.

Heu, S., J. Oh, Y. Kang, S. Ryu, S. K. Cho, Y. Cho, and M. Cho. 2001. gly gene cloning and expression and purification of glycinecin A, a bacteriocin produced by Xanthomonas campestris pv. glycines 8ra. Appl. Environ. Microbiol. 67:4105-4110.

Ivanova, I. V., P. Kabadjova, A. Pantev, S. Danova, and X. Dousset. 2000. Detection, purification and partial characterization of a novel bacteriocin substance produced by Lactococcus lactis ssp. lactis B14 isolated from boza-Bulgarian traditional cereal beverage. Biocatalysis 41:47-53.

Kırmacı, H., B. H. Özer, M. Akçelik, and N. Akçelïk. 2015. Identification and characterisation of lactic acid bacteria isolated from traditional Urfa cheese. Int. J. Dairy Technol. 69:301-307.

Klaenhammer, T. R. 1988. Bacteriocins of lactic acid bacteria. Biochimie 70:337-349.

Moraes, P. M., L. M. Perin, S. D. Todorov, A. Silva, B. D. G. M. Franco, and L. A. Nero. 2012. Bacteriocinogenic and virulence po- tential of Enterococcus isolates obtained from raw milk and cheese. J. Appl. Microbiol. 113:318-328.

Ortolani, M. B. T., A. K. Yamazi, P. M. Moraes, G. N. Viçosa, and L. A. Nero. 2010. Microbiological quality and safety of raw milk and soft cheese and detection of autochthonous lactic acid bacteria with antagonistic activity against Listeria monocytogenes, Salmonella spp., and Staphylococcus aureus. Foodborne Pathog. Dis. 7:175-180.

Perin, L. M., P. M. Moraes, G. N. Viçosa, A. Silva Jr., and L. A. Nero. 2012. Identification of bacteriocinogenic Lactococcus isolates from raw milk and cheese capable of producing nisin A and nisin Z. Int. Dairy J. 25:46-51.

Perin, L. M., and L. A. Nero. 2014. Antagonistic lactic acid bacteria isolated from goat milk and identification of a novel nisin variant Lactococcus lactis. BMC Microbiol. 14:36.

Vera Pingitore, E. V., S. D. Todorov, F. Sesma, and B. D. G. M. Franco. 2012. Application of bacteriocinogenic Enterococcus mundtii CRL35 and Enterococcus faecium ST88Ch in the control of Listeria monocytogenes in fresh Minas cheese. Food Microbiol. 32:38-47.

Rehaiem, A., B. Martínez, M. Manai, and A. Rodríguez. 2012. Technological performance of the enterocin A producer Enterococcus faecium MMRA as a protective adjunct culture to enhance hygienic and sensory attributes of traditional fermented milk 'Rayeb.' Food Bioproc. Techol. 5:2140-2150.

Robredo, B., K. V. Singh, F. Baquero, B. E. Murray, and C. Torres. 1999. From vanA Enterococcus hirae to vanA Enterococcus faecium: A study of feed supplementation with aoparcin and tylosin in young chickens. Antimicrob. Agents Chemother. 43:1137-1143.

Ross, R. P., C. Stanton, C. Hill, G. F. Fitzgerald, and A. Coffey. 2000. Novel cultures for cheese improvement. Trends Food Sci. Technol. 11:96-104.

Swaminathan, B., and P. Gerner-Smidt. 2007. The epidemiology of human listeriosis. Microbes Infect. 9:1236-1243.

Todorov, S. D., and L. M. T. Dicks. 2005. Optimization of bacteriocin ST311LD production by Enterococcus faecium ST311LD, isolated from spoiled black olives. J. Microbiol. 43:370.

Todorov, S. D., and L. M. T. Dicks. 2006. Screening for bacteriocin-producing lactic acid bacteria from boza, a traditional cereal beverage from Bulgaria: Comparison of the bacteriocins. Process Biochem. 41:11-19.

Todorov, S. D., P. Ho, M. Vaz-Velho, and L. M. T. Dicks. 2010. Characterization of bacteriocins produced by two strains of Lactobacillus plantarum isolated from Beloura and Chouriço, traditional pork products from Portugal. Meat Sci. 84:334-343.

Tulini, F. L., L. K. Winkelströter, and E. C. P. De Martinis. 2013 Identification and evaluation of the probiotic potential of Lactobacillus paraplantarum FT259, a bacteriocinogenic strain isolated from Brazilian semi-hard artisanal cheese. Anaerobe 22:57-63.

Tuncer, B. Ö., A. Y. Zeliha, and Y. Tuncer. 2013. Occurrence of enterocin genes, virulence factors, and antibiotic resistance in 3 bacteriocin-producer Enterococcus faecium strains isolated from Turkish tulum cheese. Turk. J. Biol. 37:443-449.

de Vuyst, L., and E. J. Vandamme. 1994. Bacteriocins of Lactic Acid Bacteria: Microbiology, Genetics and Applications. Blackie Academic \& Professional, London, UK. 